University of Canterbury e-Learning Lab

Davis, N.E. \& Loveless, A. (2011 in press). Editorial. Reviewing the landscape of ICT and teacher education over 20 years and looking forward to the future. Technology, Pedagogy and Education, 20(3).

\title{
Reviewing the landscape of ICT and teacher education over 20 years and looking forward to the future
}

Niki Davis, University of Canterbury, New Zealand

Avril Loveless, University of Brighton, United Kingdom

\begin{abstract}
In 1992 JITTE was the first journal in its field and some said that there were not enough scholars to fill its issues. This special issue celebrates the very fertile field that is spread before us twenty years later with reviews of the landscape of ICT and teacher education. Peer reviewed papers by the journal's editorial board provide thought provoking perspectives on the development of the field over one or two decades, including reviews of belief, pedagogy and the ways in which teacher and teacher educators have responded to ICT. This editorial also reveals influences on the scholarship of initial teacher education and digital technologies, including the editorials of this journal. Research that is starting to provide glimpses of alternative futures and the reviews in this journal, it is not difficult to see that the journal has a place in the landscape for decades to come.
\end{abstract}

\section{Introduction}

This journal has represented and recorded research in information technology for teacher education over two decades of change and development in international practice and policy. This special issue engages with the theme of 'Reviewing the Landscape' in order to reflect upon some contemporary research themes, mindful of how the scope of the research enquiry in this international community has developed over the years. The journal has borne witness to changes in the questions and contexts of research in the field, from early questions focused information and communication technologies (ICT) in teacher education, through the development of theoretical and methodological frameworks for research enquiry, to more nuanced understandings of the role of educators using digital technologies to enhance our learning lives in the diverse cultures and complex worlds of a globalised 'digital age'.

1992 was the year of the first issue of the Journal of Information Technology for Teacher Education edited by Brent Robinson under the auspices of the Association for Information Technology in Teacher Education (ITTE). In 2012 
the journal is now titled the Technology, Pedagogy and Education will reach its $20^{\text {th }}$ anniversary edited by Steve Kennewell. The Editorial Board invited the remaining long standing editors Niki Davis (1995-2000) and Avril Loveless (2000-2007) to lead this special issue. The first section of this Editorial looks back in order to celebrate and appreciate what this journal has achieved. It is followed by a review of the papers that review the landscape, before we take the challenging step of looking forward.

\section{Looking back over the evolution of JITTE/JTPE}

Established in 1992 by the UK Association for Information Technology in Teacher Education (ITTE), the Journal of Information Technology for Teacher Education (JITTE) was published by Triangle Press. This was a time in the UK when many teacher educators were new to research and the journal assisted in the building of capacity worldwide. JITTE was first international journal in its field. Our goal was to nurture scholars in this newly emerging field including the teacher researchers with whom many of worked alongside or taught.

The journal's original title was 'Journal of Information Technology for Teacher Education', the little word for having great significance in its aim to support and enhance the use of information and communications technologies (ICT) in the context of the professional development of educators, from initial or preservice teacher education to continuing professional development. The context may be hard for some readers to envisage because there were no requirements to incorporate Information Technology in initial teacher education in 1992 and the World Wide Web had yet to be invented.

Understandings of teacher education have always encompassed a wide range of contexts, from schools to colleges and higher education. The first article in the first issue was Davis' review of the previous ten years of IT in teacher education in which she stressed 'the central importance of teacher education' to the whole educational system for effective use of digital technologies (Davis, 1992). In the late 1980s colleagues in ITTE fought for recognition and resources to integrate IT in teacher education in the UK, provoked a national review - The Trotter Report (DES 1989) - and 'won' detailed requirements for the experience of student teachers preparing to support learning and teaching with digital technologies. The first issue also contained an article focused on Project INTENT, the first national project in the world that aimed to integrate information technology into teacher education. Somekh et al's (1992) article focused on 'training institutions and how they can respond' to the then new 'statutory obligation to ensure that pupils are exposed to technology' and the requirement for 'identifiable technology components' in all initial teacher education programmes. This is a continuing theme for our field.

A major goal in Project INTENT was to move on from the skills-based approach to model effective discipline specific applications of IT that also provided the opportunity to develop IT skills. Today this is recognised in Mishra and Kohler's TPACK framework - technology pedagogic content knowledge (Mishra and Koehler, 2006). There were similar concerns in other parts of the world, especially North America as described by Harrington (1992) in that first issue of 
JITTE. Project INTENT also developed the research capacity of its many participants and disseminated them in a short run of six issues of journal called Developing Information Technology in Teacher Education (DITTE) edited by Bridget Somekh and published by the UK National Council for Educational Technology. Somekh (1992: 3) concluded the series in her final editorial as follows:

The range and detail of the [30] papers in the DITTE series reflect the hard work and professional vision of all those who have been involved in any way in Project INTENT. Taken as a whole, I believe that DITTE makes a contribution of some significance to the literature on IT development in initial teacher education.

Such capacity building also helped to establish the field and JITTE.

The first issue of JITTE therefore presented an account of the questions and actions needed to inform an emergent field in research, practice and policy. It was the research voice of a community fighting for a place in policy debates and teacher education curriculum development. In its first decade the journal published articles which reflected the early adoption of ICT in teacher education, and the early innovations and interventions with particular technologies such as computer assisted learning within subject domains, communications and online networks. It raised research questions about training needs and perceptions of digital technologies in learning and teaching in professional development. Its scope was international. In the first five years, researchers from 11 countries contributed to the issues, although three quarters of these were from the UK and USA.

In 1995 the Editorial Board made the decision to have a special issue each year. Although partly pragmatic to stimulate leading scholars to focus on topic areas in which that are passionate and expert is also aimed to reduce the load on the Editor of the journal, the special issues have enabled more proactive scholarship. Through the editorials the journal also provided a commentary of the field. Appendix 1 lists the editorials of the first 20 volumes presented order of publication with an emphasis on the titles of the special issues to help them stand out. The third special issue in 1995 capitalised on Niki Davis' passion and scholarship in telecommunications which is a theme that has recurred over the decades including a special issue in 2007 edited by Paul Kirschner and KwokWing Lai on the topic of online communities of practice.

Moving into its second decade, the journal changed its name to 'Technology, Pedagogy and Education' in Volume 12 2003. The change was proposed to acknowledge how the scope of the research interests, activities and contexts had widened over the first decade. The vision to develop a journal to promote the advance of research and scholarship in the field of teacher education and to offer a platform for the debate of issues was still clear. There was, however, also recognition of how teachers' knowledge in using ICT appropriately and critically was having an impact on the field of teacher education. This challenged professional identities and the boundaries of the different communities engaged in learning and teaching with digital technologies. Pedagogical settings were changing in people's learning experiences, and the journal addressed the 
challenges to pedagogy, curriculum and context in the professional development of educators. Pedagogy has been an ongoing theme.

The first special issue under the title of TPE in 2003 was led by Paul Kirschner of the Open University of the Netherlands to publish the project he had led to produce international benchmarks for modelling teacher training in ICT, researched with case studies of good practice the use of ICT as 'core technology' in five countries (Kirschner \& Selinger, 2003). This quick scan study did not have adequate resources so there was no representation of Indigenous Peoples, and this problem of representation reoccurs today. It drew attention to key actors in professional development in teacher education institutions and providers, which include universities, research and development agencies, teacher educators, students, practising teachers, pupils, governments and society in general. The wider, international landscape of policy initiatives at the time included the UNESCO initiative to publish guidance for ICT and Teacher Education led by Paul Resta and Mariana Patru (UNESCO 2002) and the large 'Preparing Tomorrow's Teachers to use Technology' (PT3) funding programme in the USA (Brush 2003).

In the following few years of the journal, the topics of the articles highlighted the developing maturity in the field internationally, from theoretical frameworks to emergent technologies and the design of online learning environments. The role of digital technologies in change at the turn of the century was complex, and the chaotic challenges to leadership in teacher education and professional development were recognized internationally, including a JITTE special issue edited by Zharl Schoeny with support from Niki Davis (2002).

However, the quality of the research in this field was criticized and in 2004, when Jean Underwood (2004) edited a Special issue which threw down the gauntlet to the research community to develop sound theoretical underpinnings; acknowledge the history of research in the field; identify insightful research questions; and use appropriate methodologies. McDougall and Jones (2006) developed this argument for more research which was underpinned by theoretical understandings of processes of learning and teaching, rather than evaluations of short term cost benefits of the effectiveness of particular digital technologies in education. They called for research studies which are more complex, difficult and time-consuming. That theme continues today in the Edusummit that will be introduced later.

In the most recent five year span the authors of articles represent research undertaken in 27 countries, with just over half being from UK and USA. Special issues add to the international perspectives. Most recently, the special issue on whole class interactive technologies edited by Sara Hennessy and Paul Warwick permitted TPE to publish scholarship that is widely impacting classrooms of many first world countries. Hennesy and Warwick (2010: 127) capitalized on an international conference and they explained their strategy as follows:

This themed issue contains a selection of papers associated with presentations at the International Conference on Research Into Teaching with Whole class Interactive Technologies (RITWIT) hosted at the University of Cambridge, UK, in June 2009 (http://www.educ.cam.ac.uk/events/conferences/ritwit/). The conference focused on research into the pedagogy underlying use of technologies in 
the whole-class context, including innovative tools such as interactive whiteboards (IWBs), visualisers, tablet PCs, and handheld devices, asking how their use facilitates or inhibits more effective whole-class teaching and learning at school level. Implications for teacher development and educational policy were also addressed. The conference was attended by 85 delegates, 25 of them from outside the UK, representing 14 countries spanning five continents. Attendees included academic researchers, teacher educators, school leaders and classroom teachers (many of whom presented), local authority representatives and advisers, independent consultants, publishers, plus educational representatives from Becta (formerly known as the British Educational and Communications Technology Agency), UNESCO, and the main IWB and voting system distributors. In addition to attending and participating in presentations, this diverse group of delegates engaged in some very thought-provoking dialogue during a number of dedicated small-group and whole-group discussion sessions and we hope to capture the flavor of some of it in this themed issue.

This journal provided an important early lead for more open scholarly publishing in 1992. We were fortunate to have recruited a remarkable publisher Roger Osborn-King who was happy to facilitate open access to our journal that was in some way a forerunner of the Open Educational Resources that have evolved today. The business model was underpinned by sales of the paper version of the journal was marketed in the usual way, including a copy for all ITTE members as part of their subscription. In addition, the online version of the volumes published by Triangle was free to view and this continues through the Taylor and Frances web site for those earlier volumes. It was delightful for us as teacher educators to be able to refer our students and colleagues to relevant articles that they could access with ease. This brave lead was followed by other journals in this field, most notably the Society of IT in Teacher Education's Current Issues in Information Technology and Teacher Education, which Niki Davis assisted as a founding member of both Editorial Boards. Readers who are interested in this aspect are recommended Willis and Bull's (2000) editorial for the first issue of CITE that describes our growing understanding of ways to open up scholarly publication.

In summary this journal has grown with four chief editors, a period of joint editorship and many guest editors. When Triangle merged with other publishers, JITTE moved to the prestigious Routledge/Taylor \& Francis stable. In its twentieth year TPE's quality was recognized and included in the Social Sciences Citation Index®. Table 1 provides an overview over the years. The journal's editors, editorial board, reviewers and authors represent a community of researchers and scholars witnessing and shaping enquiry in the field. We acknowledge and thank them all, not least our long standing editorial assistant Sarah who joined the team in 1998 and remains a key member of the editorial and publishing team.

\section{Table 1. JITTE/JTPE's evolution over the years - Significant events}

1986 The Association of Information Technology and Teacher Education (ITTE) was founded in the UK with Roger Keeling as inaugural Chair (Davis 1992). 
1989 The Trotter Report on Information Technology in initial teacher training in the UK (DES 1989).

1990 ITTE futuring retreat 'Education 2010' (Keeling \& Whitman, 1989).

Founding of the Society of Information Technology and Teacher Education in the USA (Davis 2002).

1991 Niki Davis when chair of ITTE, provides a keynote to SITE that becomes the first paper in the first issue of JITTE the following year (Davis 1992).

1992 JITTE founded by ITTE with Brent Robinson as founding editor.

1993 ITTE and SITE sign an Accord that shares membership privileges across both associations with ITTE's decision to become more international through collaboration with SITE. SITE starts its first journal the Journal of Technology and Teacher Education (JTATE) with founding editors Jerry Willis and Dee Anna Willis published by AACE.

1993 The first special issue led by Betty Collis (see Appendix 1)

1994 JITTE increased to three issues per year

1996 Niki Davis became the JITTE Editor following the untimely death of Brent Robinson

1998 Sarah Delmas became the editorial assistant for the journal

1999 Avril Loveless became chair of ITTE

1999 Patrick Dillon and Michelle Selinger joined Niki Davis in Editing JITTE.

2000 Current Issues in IT and Teacher Education joined the journals in this field the second journal to go online with free access.

2002 Avril Loveless became the fifth editor of JITTE with issue 10(3). UNESCO publishes a guide to ICT in teacher education in English followed by editions in many other languages.

2003 JITTE changed title to TPE. TPE moved publishers from Triangle to Routledge/Taylor \& Francis (later issues not free to access online); World Summit on the Information Society call for increased equity includes ICT and teacher education (Davis \& Carlsen 2004)

2004 Jean Underwood's TPE special issue calls for increased quality following the UK research assessment exercise

2008 Steve Kennewell became the editor of TPE.

2009 First Edusummit is held in The Hague following publication of Voogt and Kenezek's (2008) 
2011 TPE's $20^{\text {th }}$ volume is celebrated with this special issue. TPE iincluded within the Social Sciences Citation Index®. Second Edusummit is held at UNESCO's headquarters in Paris.

\section{Reviewing the landscape}

In 1992, Project INTENT posed the research question 'Can quality in learning be enhanced by IT?' (Somekh et al, 1992). Twenty years later, in 2012, we reflect on how far we have come in our understanding of learning and teaching with digital technologies, through developments in theories and methodologies to describe and explain what is happening and why. Our maturing scholarship increased understanding of educational systems and the co-evolution of education and digital technologies. The question now might be posed as 'How can quality in learning lives be enhanced by digital technologies?'

The articles in this special issue are varied in their focus, yet offer different perspectives on reviewing the landscape of technology, pedagogy and education.

Fisher, Denning and Higgins' article analyses the corpus of abstracts of all the articles published over twenty years in the journal volumes $1-19$. This period reflects the change in education technologies and their role in teacher education and professional development. Using both simple word clouds and more complex text mining techniques based on latent semantic analysis, the work describes how the articles in the journal reflect the changes in the wider landscape of activity in the field. The patterns and commentary demonstrate that the research activity represented in this Journal is underpinned by some consistent themes, whilst others have reflected distinctive changes in technologies, approaches, practices and contexts in the research communities.

Hammond's analysis draws upon the 'institutional memory' of 15 longstanding members of the Association for Information Technology in Teacher Education (ITTE), this journal's parent association. Each participant had used ICT in his or her own teaching, carried out research into ICT in education and supported others in using ICT in their practice for decades. The article explores understanding of beliefs about knowing and learning and their relationship to the digital technologies encountered over a long period of practice in teacher education. Although the 'twoway' relationship was not straightforward or easy to capture, the technology could be understood both as a means for carrying out pre-specified actions and an object of enquiry in its own right. For some, the technology 'changed the subject', and yet its potential was also recognized in the wider context of beliefs about knowledge, learning and teaching.

Unfortunately the ethical consents for Hammond et al's research did not permit identification of the participants because links to their articles in this journal over the years would have added another dimension to their scholarship and research. In the future ethical procedures developed for research with and by Indigenous Peoples would better inform our field, such as that developed and promoted in New Zealand (see Rangahau: The website http://www.rangahau.co.nz ).

The article by Loveless reflects on the accomplishment of what teachers know, do and believe in a 'digital age'. The starting point for an article published in the journal in 2004 (Webb and Cox, 2004) which was a substantial review of current 
understandings of pedagogy and ICT in formal educational settings. This review in 2012 considers three theoretical frameworks for describing and explaining teachers' knowledge and practice with digital technologies, and discusses examples of the expression of pedagogy which incorporates ICT. It argues that teacher knowledge in our times is constructive, interactive and complex and 'accomplished' by reflexive professionals aware of the relationships between content, context and tools for learning and teaching.

Underwood and Dillon's article reflects on the research in the field over a decade and draws together an overview of studies which explore how teachers have responded to digital technologies being a 'core part of the teaching toolkit'. Far from presenting a deficit model of luddite teachers being barriers to development, this work argues that methodologies for maturity modeling can illuminate technological change in school contexts and teaching practices including those of teacher education. They end by warning of a "Toffler crisis", because the pace of change continues to accelerate and, as Toffler (1970) noted, the resulting potential 'future shock' can cause disorientation. This is most dangerous for educational leaders because of the need for distributed leadership and vision for effective ICT in education (Fullan 2011).

\section{Looking forwards}

Three years before JITTE was founded ITTE held a retreat in Wales to develop resources for use in teacher education that reflected on possible future with ICT in school education. The resources in 'Education 2010' edited by Roger Keeling and Senga Whitman (1992) provide scenarios that as it turned out were not so far off the mark - there are many schools similar to High Tech High. The migration challenges that Niki foresaw have sadly come to pass and are much more influential than even she envisaged. Some of the more optimistic views are possible while a few remain more like science fiction.

In 2006, Avril's editorial, entitled 'Imagining the Future: imitation or innovation?' was provoked by thinking about the challenges of globalization and constructions of the 'information society' to international contemporary education systems alongside three working groups from the Education Committee of IFIP (International Federation for Information Processing) at a working conference in Alesund, Norway. Researchers engaged in the use of digital technologies in teacher professional development were drawing upon a range of theoretical frameworks and research methodologies to address the questions in the field. These questions sought greater understanding of the interactions between people and digital technologies as cultural artefacts, the characteristics of communities of practice, the implications of multiliteracies, the design of learning environments and the competences needed to participate fully and critically in a 'Digital Age'.

On way to inform change in this very complex area is to develop future scenarios and engage leaders in their use, while also recognising that leadership must be distributed within, across and beyond organisations in each educational system. This research can be used to reduce the disorientation of leaders with the experience of 'future shock' and thus permit more resilient organisational 
maturation. Three examples of futureing projects follow. All provide more overarching perspectives than have been common to date.

In Europe Redecker et al's (2011) project 'The Future of Learning: New Ways to Learn New Skills for Future Jobs' synthesized the findings of a series of four online consultations on the future to suggest that:

while the existing physical and formal structures of education and training will remain intact, schools and universities will change significantly with respect to pedagogical strategies. Learning and teaching processes will be more flexible in addressing and implementing individual needs and preferences. Teachers will become mentors and guides in self-regulated, personalised and collaborative learning processes. Schools as institutions will open up to society by integrating external learning resources and practical learning opportunities. Technology will assist learning institutions in facilitating both, personalisation and institutional flexibility. (http://ipts.jrc.ec.europa.eu/publications/pub.cfm?id=3659)

The Knowledge Works think tank in the USA foresee the future as follows:

Major forces of change are challenging us to realize a world of learning that puts learners at the center, leverages technologies and human capital in new ways, and incorporates new structures. This world of learning will make it possible for all learners to develop deep knowledge and abilities in order to thrive throughout their lifetimes. ... Key opportunities include expanding leadership, growing deep connections in place, exploring diverse learning agent roles, repositioning learning with your public, developing skills in education transition, and supporting new forms of assessment and alternative credentialing. (see http://blog.futureofed.org/wpcontent/uploads/2011 forecast update.pdf)

As a final illustration, it may be interesting for readers to know of research project that Niki Davis is leading to create a set of scenarios for the future of New Zealand tertiary education in 2016. It is the first time that a nationwide target has been attempted and it includes teacher education. Drawing upon the JISC (n.d.) tool kit, the project's aim is to provoke New Zealand leaders to move towards more effective and equitable education by informing those involved in tertiary education of possible futures (see http://akoaotearoa.ac.nz/projects/2016-scenario-guide-effective-tertiaryeducation-new-zealand). The research methodology starts with interview so leaders and before online social networking of the scenario set in 2011.This emergent research is thus also an example of recent research that embeds ICT within its methodology and recognises the increasing speed of evolution of ICT and education.

\section{Summary and conclusion}

In 2012 we are reaping the whirlwind of globalization and 'the information society'. Many are facing straitened times in educational research funding, in a 
context where the ideology underpinning education policy in developed countries has shifted from 'entitlement and coherence' to 'competition and diversity'. The public and charitable foundation resources are more limited, yet the research questions are bigger. For example, in the UK, the ESRC strategic priorities for 2011 - 2015 reflect some of the concerns of our times: Economic Performance and Sustainable Growth; Influencing Behaviour and Informing Interventions; A Vibrant and Fair Society.

The quest for a more equitable society locally and globally underpins the mission of ITTE and this journal. Through SITE, ITTE was one of the sponsors of the EDUSummIT held at UNESCO's headquarters in Paris in June 2011, which focused on 'building a global community of policymakers, educators and researchers to move education into the digital age'. Drawing on the outcomes of the first summit in 2009, which was underpinned by 2008 Handbook of IT in primary and secondary education (Voogt \& Knezek 2008), eight themes were identified for discussion at UNESCO with experts invited from all parts of the world. The themes of organizational change, assessment, conditions for learning, $21^{\text {st }}$ century skills and teacher professional development in a context where educators might be guides, mentors, friends and partners in self-regulated, personalised and collaborative learning processes are applied to education in K12 schools and teacher education. Table 2 lists the eight themes debated at the summit with related points from the Edusummit 2009 Call to Action (see http://edusummit.nl).

Table 2. The Edusummit 2011 themes with related points from the Edusummit 2009 Call to Action (see http://edusummit.nl)

Restructuring educational systems to move into the digital age

- To radically restructure schools to be able to use multiple technology-enhanced pedagogies to address individual needs of students

- To develop and use distributed leadership models for technology use in schools and teacher education programs

\section{2: Student technology experiences}

- To establish a clear view on the role of ICT in 21st century learning and its implications for formal and informal learning

- To better understand student technology experiences in informal learning environments, in order to inform learning in formal settings

\section{3: Teacher professional development}

- To develop and use models for teacher learning on technology use in schools and classrooms at the pre- and in-service levels

\section{4: Global awareness}

- To develop ideas on international opportunities relating to new 
and emerging technologies in order to address the needs of developing countries and promote global social awareness and responsibilities

\section{5: Assessment}

- To develop new assessments designed to measure outcomes from technology enriched learning experiences

\section{6: 21st century learning}

- To establish a clear view on the role of ICT in 21st century learning and its implications for formal and informal learning.

\section{7: Barriers / Essential conditions}

- To develop and disseminate a list of essential conditions that need to be in place to ensure benefit from technology investments

\section{8: Researching ICT in education}

- To actively study both research on and development of ICT applications in classrooms

- To develop mechanisms for sharing and distributing research, promising policies and practices on ICT in education

One of the 2011 Edusummit recommendations is that it and UNESCO work with Indigenous Peoples to identify ways in which ICT can be restructured to build their capacity for self determination. Culturally sensitive teacher education with ICT is a key topic that is too rare in this and other journals. We hope that this review will also serve to increase the research in this important area of teacher education.

In conclusion, these reviews of the landscape of ICT and teacher education over 20 years and our forward look to the future provide plenty of evidence that ICT and education are co-evolving and that evolution is gathering speed. The change literature analysed during the Edusummits and in this journal's articles and special issues indicates that there are many potential futures towards which we are evolving. As Underwood and Dillon indicate in this issue, there is a potential 'Toffler crisis'. One of the most complex fields must be ICT and teacher education because it operates across the systems of compulsory schooling and tertiary education with fast evolving technologies and systems. This is the field that this journal was established to serve two decades ago. Therefore this journal has an increasingly important role to play in the future and we look forward to the support of the international scholarly community. 


\section{References}

Brush, T. (2003). Introduction to the special issue on Preparing Tomorrow's Teachers to use Technology (PT3). Educational Technology Research and Development, 51(1), 39-40.

Davis NE (1992) Information Technology in UK initial teacher education 19821992. Journal of IT in Teacher Education, 1(1), 7-22.

Davis, N.E. (2002) Leadership of information technology for teacher education: a discussion of complex systems with dynamic models to inform shared leadership. Technology, Pedagogy and Education, 11, 253-272.

Davis N.E. \& Carlsen R. (2004) A comprehensive synthesis on research into information technology in education. In Tom van Weert (ed.) World Summit on the Information Society forum Engineering and the Knowledge Society: Information technology supporting human development. IFIP and WFEO, Geneva, December 2003. Kluwer Academic Publishers, Amsterdam.

DES (1989). Information Technology in Initial Teacher Training: report of the expert working group. London: Her Majesty's Stationery Office.

Fullan, M. (2011, May). Choosing the wrong drivers for whole system reform. Centre for Strategic Education Seminar Series Paper No. 204, Vicroria: Centre for Strategic Education.

Harrington, H. (1992). Fostering critical reflection through technology: preparing prospective teachers for a changing society. Journal of IT in Teacher Education, 1(1), 67-82.

Hennessy, S. \& Warwick, P. (2010): Research into teaching with whole-class interactive technologies, Technology, Pedagogy and Education, 19:2, 127-131. http://dx.doi.org/10.1080/1475939X.2010.491211

JISC (n.d.). Scenario planning. Retrieved July 25, 2011 from http://www.jiscinfonet.ac.uk/tools/scenario-planning

Johnson, L., Smith, R., Levine, A., \& Haywood, K. (2010). The 2010 Horizon Report: Australia-New Zealand Edition. Austin, Texas: The New Media Consortium.

Kirschner, P. \& Selinger, M. (2003). Editorial: The state of affairs of teacher education with respect to information and communications technology. Journal of IT in Teacher Education, 12(1), 5-7.

MCDOUGALL, A. \& JONES, A. (2006) Theory and history, questions and methodology: current and future issues in research into ICT in education. . Technology, Pedagogy and Education, 15, 353-360.

Keeling, R. and Whitman, S. (eds.) (1989). Education 2010. Birmingham, UK: Newman College. 
MISHRA, P. \& KOEHLER, M. J. (2006) Technological Pedagogical Content Knowledge: A Framework for Teacher Knowledge. Teachers College Record, 108, 38-1054.

Redecker, C., Leis, M., Leendertse, M., Gijsbers, G., Punie, Y., Kirschner, P., Stoyanov, S. \& Hoogveld, B. (2010). The Future of Learning: New Ways to Learn New Skills for Future Jobs. EUR Number: Technical Note JRC60869. Retrieved July 10, 2011 from http://ipts.jrc.ec.europa.eu/publications/pub.cfm?id=3659)

Schoeny, Z. (2002). Editorial: Leadership of Information Technology in Education. Journal of IT in Teacher Education, 11(3).

Somekh, B. (1992). Editorial. Developing Information Technology in Teacher Education, Number 6, 1-3.

Somekh B, Blackmore M., Blythe K, Byrne Hill G, Clemson D, Coveney R, Davis N.E., Jessel J, Taylor, C and Vaughan G (1992). A research approach to Information Technology development in initial teacher education. Journal of Information Technology for Teacher Education, 1(1), 83-99.

Toffler, A. (1970). Future Shock. New York: Bantam Books.

Underwood, J. (2004). Editorial. Research into information and communications technologies: where now? Journal of Information Technology for Teacher Education, 13(2), 135-145.

UNESCO (2002). ICT in teacher education. A planning guide. UNESCO: Paris, France. Retrieved December 14, 2010 from http://unesdoc.unesco.org/images/0012/001295/129533e.pdf

J. Voogt and G. Knezek (eds.) (2008). International Handbook of Information Technology in Primary and Secondary Education, Amsterdam: Springer.

WEBB, M. \& COX, M. (2004) A Review of Pedagogy Related to Information and Communications Technology. Technology Pedagogy and Education, 13, 52-286.

Willis, J., \& Bull, G. (2000). Setting the priorities: Electronic scholarly publishing for instructional technology and teacher education. Contemporary Issues in Technology and Teacher Education, Retrieved July 30, 2011 from http://www.citejournal.org/vol1/iss1/editorials/article2.htm

Davis, N. (2002). SITE: From our society's foundation toward shared leadership for an intercultural future. Contemporary Issues in Technology and Teacher Education, 2(2). Retrieved July 30, 2011 from http://www.citejournal.org/vol2/iss2/editorials/article1.cfm

Appendix 1. Editorials of JITTE/JTPE over the first 20 years (spreadsheet file) 